\title{
Proceeding
}

Supplementary Issue: Summer Conferences of Sports Science. Costa Blanca Sports Science Events, 25-26 September 2020. Alicante, Spain.

\section{ICT in investigative training for students of physical culture in time of COVID-19}

\author{
LIDA DE LA CARIDAD SÁNCHEZ-RAMÍREZ1 $\unlhd$, AMINADAN LAÍNEZ-BONILLA², JOSÉ ELIAKIN LAÍNEZ- \\ BONILLA², NAHUN DAVID MARTÍNEZ-SARAVIA² \\ 1 University of Oriente, Santiago de Cuba, Cuba \\ ${ }^{2}$ National Autonomous University of Honduras, Tegucigalpa, Honduras
}

\begin{abstract}
In the era of ICT, training for research in higher education is one of the links for the success of future professional results of Physical Culture, however, there are currently limitations. The purpose of evaluating the validity of the didactic strategy aimed at guiding the actions for the preparation, execution and evaluation of the investigative training in the student of the Physical culture career in times of contingency (COVID-19). The methodology used is the document review (use of typical search tools on the Web), the systemic structural - functional method and the "expert criteria" method. 15 (5\% error) specialists were selected from the self-evaluation test. A level of concordance was reached, with the use of the Kendall test, of very adequate for the practical application of the strategy.

Keywords: Didactic strategy; Search tools; Higher education.

\section{Cite this article as:}

Sánchez-Ramírez, L.C., Laínez-Bonilla, A., Laínez-Bonilla, J.E., \& Martínez-Saravia, N.D. (2020). ICT in investigative training for students of physical culture in time of COVID-19. Journal of Human Sport and Exercise, 15(4proc), S1488-S1499. doi:https://doi.org/10.14198/jhse.2020.15.Proc4.45
\end{abstract}

Corresponding author. University of Oriente, 90600 Santiago de Cuba, Cuba. https://orcid.org/0000-0003-1782-6194 E-mail: lidin2610@gmail.com Abstract submitted to: Spring Conferences of Sports Science. Costa Blanca Sports Science Events, 19-20 June 2020. Alicante, Spain.

JOURNAL OF HUMAN SPORT \& EXERCISE ISSN 1988-5202

(c) Faculty of Education. University of Alicante doi:10.14198/jhse.2020.15.Proc4.45 


\section{INTRODUCTION}

The new model of a University must pay special attention to the use of Information and Communication Technologies (ICT) and recognize the enormous impact that technological development produces in the information and knowledge society and its influence on learning (Sánchez, 2013).

In this sense, the training needs of the professionals of the XXI century, universities cannot reserve all the contents of the scientific work and even less can professors be reservoirs of all information. The scientific contents are not concluded truths, but are in a constant dynamic, hence the need for a systematic update.

In order to investigate about the training of the professional for the investigative process, a factual diagnosis was made that consisted of the revision of theses of masters and doctorates related to the training of the professional of the career in Physical Culture, of the results presented by researchers in scientific events both national and international-, of documents of the Ministry of Higher Education of Cuba, and of the Report on Higher Education in Latin America and the Caribbean; and from his own experience as a teacher, the following manifestations could be determined:

- Difficulties in the students for the development of investigative works regarding the search, obtaining and processing of the information and the communication of results;

- Limited search on the web, to access the diversity of information, and promote communication in this way;

- Insufficient exploitation of the network for exchange and consultation between students and other researchers on related topics. It is summarized that the possibilities of ICT as an information and communication resource are not applied or exploited to their full extent.

Although several university careers use ICT (use of interactive platforms or tele-training platforms) in the PEA, the use of traditional methods predominates, showing that ICTs have been used as another instrument for the search for information and in a certain way, to the communication. In this sense, the use of ICT has not succeeded in transforming the teaching-learning process (PEA), since these technologies have not been conceived with a meaning and sense of transformation to said process in general and to research training in particular.

Therefore, this study specifies as a problem: the research limitations in students of the Physical Culture career, during the PEA in the era of Information and Communication Technologies (ICT). Hence, its purpose is specified: to evaluate the validity of the didactic strategy aimed at guiding the actions for the preparation, execution and evaluation of the investigative training in the student of the Physical culture career in times of contingency (COVID-19).

\section{METHODS}

The methodology used is the documentary review of articles concerning the subject through the use of search tools on the Web (specialized search engines, databases) and the "expert criteria" method, with the Delphy methodology in order to evaluate the validity of the proposed strategy that will be applied and refined from this empirical research method. It is taken as a reference to assess the strategy to Tourón, Martín, Navarro, Pradas, Î́igo. (2018).

The stages followed in the application of the evaluation method through experts. 
1. Development of the objective: assessment of the effectiveness of the strategy.

2. Selection of experts: 15 specialists were selected from the self-assessment test with the possibility of making a $5 \%$ error.

3. Choice of methodology: Delphy or Delfos.

It begins with the preparation of the guide of aspects to be assessed by the experts, which is delivered to the experts together with the strategy developed. The information was made individually and was delivered in writing using email.

Previous step: Preparation of the double entry table of marking frequency.

Each question represents an indicator that aims to guarantee the objectivity of the information and its processing. The assessment started from the following scale: Very adequate (MA), Fairly adequate (BA), Adequate $(A)$, Not very adequate (PA), Not adequate (NA).

For the assessment of the strategy, the following dimensions (D) and indicators (I) were established:

- D. Structure: I1. Stages and 12 explanation of each component of the strategy.

- D. Relevance, effectiveness: I3. Suitability for conditions, I4 Reliability.

Once the instruments have been passed to the experts, the methodological sequence of the DELPHY method is applied.

Previous step: Preparation of the double entry table of marking frequency. With the following scale:

\begin{tabular}{|l|l|l|l|l|l|l|l|l|l|}
\hline Very Adequate & MA & Fairly Adequate & BA & Adequate & A & Little suitable & PA & Not suitable & NA \\
\hline
\end{tabular}

Subsequently, the evaluation of three attributes of the strategy with its indicators is carried out and the opinion of specialists is obtained:

1. Systemic of the didactic strategy

2. Practical implications of the didactic strategy

3. Usefulness of the didactic strategy

Table 1. Scale for the evaluation of each indicator.

\begin{tabular}{|c|c|c|c|c|}
\hline 1 & 2 & 3 & 4 & 5 \\
\hline Strongly disagree: & Disagree: & $\begin{array}{l}\text { Neither agree nor } \\
\text { disagree: }\end{array}$ & Agree: & $\begin{array}{l}\text { Strongly } \\
\text { agree: }\end{array}$ \\
\hline $\begin{array}{l}\text { If you are totally } \\
\text { dissatisfied with } \\
\text { the indicator you } \\
\text { are evaluating. }\end{array}$ & $\begin{array}{l}\text { If you consider } \\
\text { that you do not } \\
\text { approve the } \\
\text { indicators or their } \\
\text { results }\end{array}$ & $\begin{array}{l}\text { If you consider that } \\
\text { the same can accept } \\
\text { that not accept the } \\
\text { indicators that are } \\
\text { measured. }\end{array}$ & $\begin{array}{l}\text { If you agree but } \\
\text { consider that there } \\
\text { are elements that } \\
\text { can be improved. }\end{array}$ & $\begin{array}{l}\text { If you are fully } \\
\text { satisfied with } \\
\text { what is } \\
\text { required of } \\
\text { you. }\end{array}$ \\
\hline
\end{tabular}

\section{RESULTS}

According to experts, the proposed strategy is dominated by the assessment of very adequate, so that it has the necessary characteristics to fulfil its objective and solve the problem raised in the research. 
Applying Kendall's statistical test, it is obtained that the results of the evaluation of the didactic strategy carried out by the experts are statistically significant. This implies that there is sufficient evidence to establish, at $95 \%$ the reliability that the 15 experts agree on the degree of coincidence of the effectiveness of the didactic strategy, for its application in investigative training based on ICT.

The didactic strategy its general objective is declared in: guiding the actions for the preparation, execution and evaluation of the dynamics of the research training process with the use of ICT with a meaning and sense in the development of research, as well as the appropriation of competencies at work with them.

The open nature of the strategy means that its applicability can vary according to the diversity and individuality of the students, teachers and other subjects involved in the training process; It is flexible because it makes it possible to incorporate changes and make adjustments to be applied according to the particularities of those who participate in the training process, the space and context where it will take place.

The strategy contains premises and requirements. The premises constitute the context that establish the conceptualization and application of the strategy. The requirements are those scenarios for the proposal to be developed.

\section{Premises}

- Technological infrastructure associated with ICTs that have students, teachers, family members or other subjects such as specialists or experts, researchers (from the institution or outside of it, national or foreign) who participate during the PEA in an atypical way.

- Theoretical - methodological development of teachers, family, other subjects who participate in times of contingency.

\section{Requirements}

- Adequate availability and diversity of didactic - technological resources possessed by students, teachers, family members or other subjects.

- Ensure the systematic technological improvement (referring to ICT) and research of teachers.

The teachers make a diagnosis of the training needs, from the cognitive and motivational aspects of each student, theoretical and practical resources that they have to systematically guide them with the necessary flexibility to redesign the research training process with the use of ICT.

The need to update teachers from a technological and research point of view, which is achieved through any form of improvement in terms of:

- Understand the benefit of ICT for the development of the investigative process.

- Incorporate the use of ICT into their teaching practice in a systematic way.

- Use the network as a space for collaboration and exchange, which allows the optimization of resources in the development of research.

- Manage didactic and technological resources to guarantee the development and transformation of research.

Therefore, the improvement of teachers in technological matters must be specified: computer networks; the use of technological resources; cooperation and collaboration strategies in technological environments. 
These elements should allow the application of ICT in the research training process, as instruments of innovation. All this in a similar way must occur in the other subjects who participate in this process.

Related to students as builders and managers of their own learning about research, they should be reflective of their level of preparation to use ICT in the research process, in relation to: navigating and interacting on the Intranet and on the Internet, which means searching for information on the net; employ specific purpose or professional program packages related to the content of your profession; manipulate email Chat, YouTube, Messenger, Google Scholar, Cixco Webex, ZOOM, among other platforms, optimally use the diversity of technological tools such as: dynamic Web pages, participate in online scientific forums, interactive multimedia, tutorials, simulators, the use of typical search tools on the Web, among others.

In addition, possess skills to develop the state of the art of research with the use of the possibilities of ICT, which means: identification in the network of the main sources of information, search and review of localized information, record and organize information, achieve critical analysis of the selected information, communicate the information, solve the problem investigated with solutions that are distinctive that verify through the network with other colleagues in order to collect critical assessments and opinions related to the results found.

For the development of the strategy, actions should be projected at the career level, which correspond to the particular objectives that are dealt with for investigative training.

Consequently, students and teachers must have access and have a diversity of didactic-technological resources, which allows access to the plurality of articles related to the contents of their profession, so that they can select the most appropriate to solve the problems that investigate, they should use a collaborative method (Sánchez, Duany \& Pozo, 2018) with other colleagues (from inside and outside the centre, national or from abroad), which allow them to optimize the execution of the proposed activities based on the contributions that, In terms of communication (both synchronous and asynchronous), it offers the computer network (Sánchez, Duany \& Pozo, 2018).

The didactic strategy is developed in three stages: preparatory, execution and evaluation. These stages contain actions that enable the projection and organization of investigative activities where the use of ICT is its fundamental link.

\section{Preparatory stage}

Its intention is to establish awareness and preparation actions for students and teachers in the investigative process with the use of ICT:

- Diagnosing the initial state of those who participate in the process to use ICT.

- Sensitize teachers and students about the possibilities of using ICT in the research training process, ways and means to achieve it.

\section{Execution stage}

Its purpose is to develop ways to align the orderly use of ICT during the research training process that allows accessibility and availability of content, as well as to promote its construction based on collaborative work (Sánchez, Duany and Pozo, 2018).

In this sense, in the dynamics of the research training process through ICT, each teacher during the PEA is a guide to the process and will develop actions aimed at: 
- Plan and organize scientific research activities: interviews, electronic talks or conferences by experts on the subject (the latter through the blended modality or through the development of a teleconference), seminars, visits (real or virtual) of the students to work or research centres related to their spheres of action, among others; the precision of the bibliography to be used (printed or digital texts, as well as websites with information of interest, interactive multimedia related to the subject); the provision of accessibility to virtual libraries, as well as the availability of various bibliographic resources; the determination of the main didactic means that will be used for the motivation of the students during the development of the investigative activities; organization of their independent work on the subject they are investigating, which includes the preparation of study guides, which collect, among other aspects, the orientation to them from websites with valuable information that they are recommended to review, as well as general guidelines for the development of the scientific research process (Sánchez, 2009).

- Distinguish the topics to be investigated by the students. In this selection it is important to take into account: the objectives to be achieved according to the type of investigative activity in question, must be oriented from the characteristics of the students, their interests, motivations, intentionality, as well as the previous ideas, potentialities and difficulties of these, the skills to be developed, the levels of assimilation and depth that must be achieved. The research topics that are oriented to students can be of different types (real, modelled, theoretical, in academic or professional contexts), but all must lead to study, abstraction, systematization and generalization of knowledge, skills, evaluations, as well as the search for solutions (Sánchez, 2009).

In this direction, rules are determined to intervene and promote discussion and evaluations (Sánchez, 2009):

Only send short messages related (between five and ten lines) with the subject investigated.

Discussion, reflection, and assessment are between everyone (students, teacher and other subjects), but they are moderated by the teacher who intervenes under the same conditions as the rest of the participants.

Avoid appending or attaching files, so as not to lose the fluency in the debate.

The message must be identified by the name.

State why you agree (or why not), and make a previous reference to the idea you want to refute or expand; Each message that is sent for the development of the debate must contribute to contribute some distinctive element, where ideas already presented are assumed or enriched, or open new topics for discussion (Sánchez, 2009).

The debate should not be broken up or extended; To propose another idea for discussion, you must have concluded the topic that occupies the centre of the debate; When intervening, for or against ideas already stated, make sure that too much time has not passed.

A maximum of five and a minimum of two interventions are established.

Each student must take note of the ideas and the most important data that arise in the debate, since, at the end, a summary of their own participation in the discussion will be asked where a reflection on the position taken when beginning of the debate, on the evolution with respect to this first point of view and, finally, on the conclusions drawn. 


\section{Evaluation stage}

Carry out the systematic evaluation during the course of the training process, which will allow the teacher to detect the appropriation and deepening of the content, as well as its systematization, developing different activities that promote independent work, search, exchange, inquiry, the exercise, and therefore the fulfilment of the objectives of the investigative activities (Sánchez, 2009).

Evaluation criteria established by Sánchez, 2009 are established:

Criterion of 5 (excellent) Reference articles from internationally recognized journals, intervention focused on the topics of the discussion, follows the rules of the debate -the ability to synthesize is valued-, and documents the references to the scientific contents of the proposed texts as required reading; In addition to the above elements, it provides new ideas, scientific content not mentioned above and references to other materials, complementary to those proposed (interactive multimedia, web pages, simulators, recognized databases, etc.).

Criterion of 4 (good) an intervention focused on the topics of the discussion, which follows the rules of the debate -the capacity for synthesis is valued- and documents the references.

Criterion 3 (regular) an intervention focused on the topics of the discussion, follow the rules of the debate the ability to synthesize is valued-, but presents limitations in documenting the references to the scientific contents of the proposed texts as compulsory readings.

Criterion 2 (bad) an intervention not focused on the topics of the discussion, does not comply with the rules of the debate -the ability to synthesize is valued-, presents limitations in documenting the references to the scientific contents of the texts proposed as compulsory readings.

Table 2. Expert evaluation.

\begin{tabular}{lllllll}
\hline Indicators & Fairly Adequate & Quite adequate & Adequate & Little Adequate & No Suitable & Total \\
\hline $\mathrm{I}_{1}$ & 13 & 2 & 0 & 0 & 0 & 15 \\
$\mathrm{I}_{2}$ & 10 & 2 & 3 & 0 & 0 & 15 \\
$\mathrm{I}_{3}$ & 14 & 1 & 0 & 0 & 0 & 15 \\
$\mathrm{I}_{4}$ & 12 & 3 & 0 & 0 & 0 & 15 \\
\hline
\end{tabular}

Note: (l 1 . Stages, $I_{2}$ explanation of each component of the strategy, $I_{3}$ Suitability to the conditions, $I_{4}$ Reliability).

\section{Information processing}

Table 3. Cumulative frequency table.

\begin{tabular}{llllll}
\hline Indicators & Fairly Adequate & Quite Adequate & Adequate & Little Adequate & Total \\
\hline $\mathrm{I}_{1}$ & 13 & 15 & 15 & 15 & 15 \\
$\mathrm{I}_{2}$ & 10 & 12 & 15 & 15 & 15 \\
$\mathrm{I}_{3}$ & 14 & 15 & 15 & 15 & 15 \\
$\mathrm{I}_{4}$ & 12 & 15 & 15 & 15 & 15 \\
\hline
\end{tabular}

Note: ( $l_{1}$. Stages, $l_{2}$ explanation of each component of the strategy, $l_{3}$ Suitability to the conditions, $l_{4}$ Reliability).

Table 4. Cumulative relative frequency table.

\begin{tabular}{lllll}
\hline Indicators & Fairly Adequate & Quite Adequate & Adequate & Little Adequate \\
\hline $\mathrm{I}_{1}$ & 0.86666667 & 0.99975844 & 0.00000000 & 0.00000000 \\
$\mathrm{I}_{2}$ & 0.66666667 & 0.80000000 & 0.99975844 & 0.00000000 \\
\hline
\end{tabular}




\begin{tabular}{ccccc}
\hline$I_{3}$ & 0.93333333 & 0.99975844 & 0.00000000 & 0.00000000 \\
$I_{4}$ & 0.80000000 & 0.99975844 & 0.0000000 & 0.00000000 \\
\hline & Note: (11. Stages, $I_{2}$ explanation of each component of the strategy, $I_{3}$ Suitability to the conditions, $I_{4}$ Reliability).
\end{tabular}

The last column must be eliminated, since as it is about five categories we are looking for 4 cut points.

Table 5. Find the image of each of the values of the cells in the previous table, in reverse.

\begin{tabular}{lllllllll}
\hline Indicators & MA & BA & A & PA & NA & Total & Average & N-P \\
\hline$I_{1}$ & 1.110772 & 3.489949 & & & & 4.600721 & 1.150180 & 0.344670 \\
$I_{2}$ & 0.430727 & 0.841621 & 3.489949 & & & 4.762298 & 1.190574 & 0.304276 \\
$I_{3}$ & 1.501086 & 3.489949 & & & & 4.991035 & 1.247759 & 0.247091 \\
$I_{4}$ & 0.841621 & 3.489949 & & & & 4.331571 & 1.082893 & 0.411957 \\
\hline
\end{tabular}

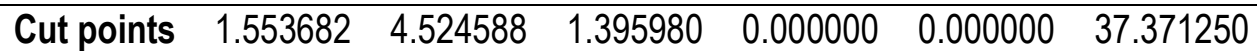

Note: ( $I_{1}$. Stages, $I_{2}$ explanation of each component of the strategy, $I_{3}$ Suitability to the conditions, $I_{4}$ Reliability). $\mathrm{N}$ is the result of dividing the sum of the sums by the product of the number of categories by the number of steps. $\mathrm{P}$ are the averages.

The cut-off points made it possible to determine the category or degree of adequacy of each step of the strategy according to the opinion of the experts consulted.

If we compare the difference (N-P) for each indicator with its points, we will have:

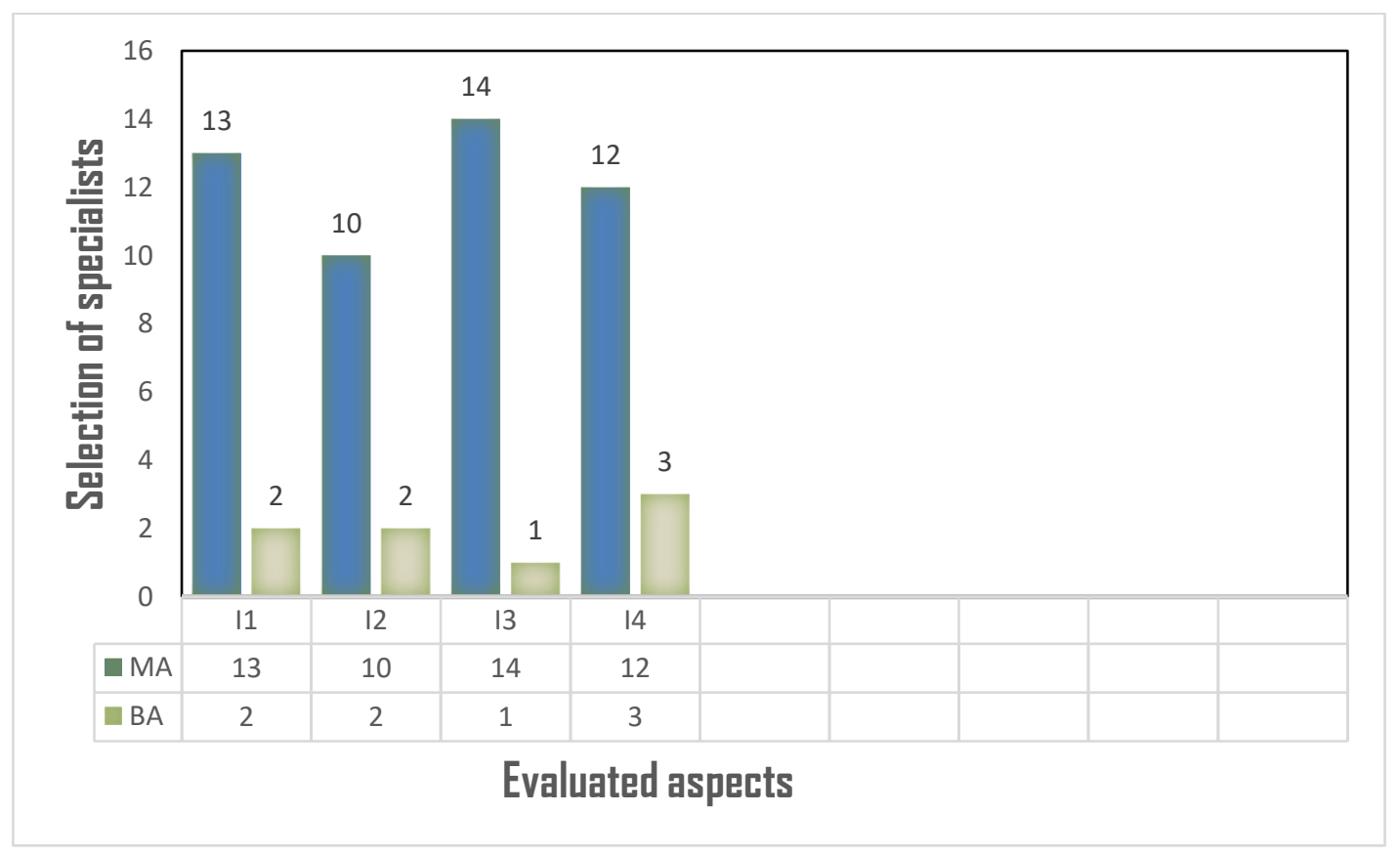

Figure 1. Results of the criteria of the experts on the assessment of the effectiveness of the strategy (Authors' elaboration).

Related to the results of the evaluation of the three attributes of the didactic strategy (See Table 6), it was obtained that more than $85 \%$ strongly agree with the interrelation (from the systemic point of view) between the components of the same (functioning as a system ) as well as with the consideration of the functional characteristics of the development of the training process for scientific research with the use of ICT. 
Table 6. Results of the evaluation of the three attributes of the didactic strategy (Author's elaboration).

\begin{tabular}{|c|c|c|c|c|c|}
\hline Attributes / Indicators & 1 & 2 & 3 & 4 & 5 \\
\hline \multicolumn{6}{|l|}{ Systemic of the didactic strategy } \\
\hline $\begin{array}{l}\text { Interrelation between the components of the didactic strategy } \\
\text { (functioning as a system). }\end{array}$ & --- & --- & --- & $\begin{array}{l}5 \\
8.0 \%\end{array}$ & $\begin{array}{l}57 \\
91.9 \%\end{array}$ \\
\hline $\begin{array}{l}\text { Consideration of the functional characteristics of the development of } \\
\text { the training process for scientific research with the use of ICT. }\end{array}$ & -- & -- & -- & $\begin{array}{l}7 \\
11.2 \%\end{array}$ & $\begin{array}{l}55 \\
88.7 \%\end{array}$ \\
\hline \multicolumn{6}{|l|}{ Practical implications of the didactic strategy } \\
\hline It contributes to the use of the possibilities of ICT in scientific activities. & --- & --- & --- & $\begin{array}{l}5 \\
8.0 \%\end{array}$ & $\begin{array}{l}57 \\
91.9 \%\end{array}$ \\
\hline $\begin{array}{l}\text { It allows the preparation for collaborative work of research projects } \\
\text { between students, professors, specialists and institutions both } \\
\text { nationally and internationally, without time and space constituting } \\
\text { barriers to achieve it. }\end{array}$ & -- & -- & -- & $\begin{array}{l}3 \\
4.8 \%\end{array}$ & $\begin{array}{l}59 \\
95.1 \%\end{array}$ \\
\hline $\begin{array}{l}\text { It allows the development of cognitive independence and collaborative } \\
\text { work that once incorporated in the students will form part of the way in } \\
\text { which, as future professionals, they relate to the world. }\end{array}$ & --- & -- & --- & $\begin{array}{l}2 \\
3.2 \%\end{array}$ & $\begin{array}{l}60 \\
96.7 \%\end{array}$ \\
\hline $\begin{array}{l}\text { The development and use of technological didactic resources, such as } \\
\text { interactive multimedia, replaces the lack of bibliographic materials, as } \\
\text { well as guarantees the current level of scientific content for the } \\
\text { development of research. }\end{array}$ & -- & -- & -- & -- & $\begin{array}{l}62 \\
100 \%\end{array}$ \\
\hline \multicolumn{6}{|l|}{ Usefulness of the didactic strategy } \\
\hline $\begin{array}{l}\text { The foundations of the didactic stra } \\
\text { epistemological conceptions about how to } \\
\text { for research with the use of ICT in univers }\end{array}$ & --- & +-- & --- & $\begin{array}{ll}2 \\
3.2 \%\end{array}$ & $\begin{array}{l}60 \\
96.7 \%\end{array}$ \\
\hline $\begin{array}{l}\text { The proposed research methods and techniques allow any teacher to } \\
\text { adequately direct research training with the use of TIC during the } \\
\text { educational teaching process. }\end{array}$ & -- & --- & -- & $\begin{array}{l}3 \\
4.8 \%\end{array}$ & $\begin{array}{l}59 \\
95.1 \%\end{array}$ \\
\hline $\begin{array}{l}\text { The didactic strategy starts from considering the professional training } \\
\text { model so that it is directed from the context of professional } \\
\text { performance, in the interaction with the subjects and the object of the } \\
\text { profession. }\end{array}$ & -- & -- & -- & $\begin{array}{l}1 \\
1.6 \%\end{array}$ & $\begin{array}{l}6 \\
98.3 \%\end{array}$ \\
\hline $\begin{array}{l}\text { Activities are offered to use technological didactic resources during the } \\
\text { teaching-educational process, taking into consideration the specific } \\
\text { conditions of each university career where the didactic strategy will be } \\
\text { inserted. }\end{array}$ & -- & -- & -- & $\begin{array}{l}5 \\
8.0 \%\end{array}$ & $\begin{array}{l}57 \\
91.9 \%\end{array}$ \\
\hline
\end{tabular}

$91 \%$ strongly agree with the practical implications of the didactic strategy, which contributes to the use of the possibilities of ICT in scientific activities. 95\% consider that it allows the preparation for collaborative work of research projects between students, professors, specialists and institutions, (both nationally and internationally) without time and space constituting barriers to achieve it. $96 \%$ agree in the previous scale that the proposal allows the development of cognitive independence and collaborative work among students, which will be part of the way in which as future professionals they relate to the world. $100 \%$ strongly agree that the development and use of didactic-technological resources, such as interactive multimedia (to name just one example) contributes to alleviating the lack of bibliographic materials, as well as guaranteeing a satisfactory level of current content scientists for the development of research. 
Regarding the usefulness of the didactic strategy, $96 \%$ strongly agree that its foundations allow updating the epistemological conceptions about how to develop the training process for research with the use of ICT by The college students; $95 \%$ agree that the proposed research methods and techniques allow any teacher to adequately direct training for research with the use of ICT during the PEA. $98.3 \%$ strongly agree that the didactic strategy starts from considering the professional training model, so that it is directed according to the context of professional performance where it will be applied in the interaction with the subjects and the object of the profession . $91.9 \%$ suggest that activities be offered to use the didactic-technological resources during the Educational Teaching Process, taking into account the specific conditions of the career.

For example, in the handball subject, students learn techniques, skills, and coordinating abilities as components of the athlete's motor capacity. The identification and description of the various elements that make up the structural complex of coordinative capacities constitutes a starting point to face their teaching and optimization. The training and the formation of the specific gestures in the handball player must be carried out by reproducing, with suitable training methods, the coordinating requirements on which motor skills are built (coupling capacity, spatial orientation).

Now, to support this process of teaching and learning the subject of handball in times of pandemic from home, the teacher can use a virtual learning platform. Through the platform, it sends emails to students, shows the schedule of activities, manages grades, exposes the course program, executes short content tests using closed questions, assigns research work and makes available to students material of Consult such as bibliography, images, videos, or other technological resources such as interactive multimedia, messenger, WhatsApp, Messenger.

\section{DISCUSSION}

From the revelation of the results emanating from the study, it is recognized that the proposed strategy can be applied to achieve research training asynchronously from the current situation where training can continue from home. In this sense, effective practical experiences have been verified in relation to the use of ICT by using forums, hangout, webinar, among others, since they allow establishing not only the exchange of ideas, the development of social and communication skills but also collaboration and cooperation. with other actors eliminated geographic barriers.

It is important to take ownership of this challenge from the perspective of professional training, around the development of skills that would be essential in the teaching process in the field of Physical Culture.

It also recognizes the aspects that, declared in the referenced literature, by specifying the relevance that the application of ICTs has for education and for the training of students not only in classrooms but from other spaces when establishing jobs and making available of the students reference material (bibliography, images, videos) as well as communication from messenger, WhatsApp, email and other resources.

Various authors (Cetz, Vásquez, Santiago, 2015) consider that the rapid development of new technologies has a great impact on ways of learning. Learning using ICT requires methodological approaches other than just the acquisition of content. In this way, the importance of the use of ICTs is recognized as they are considered as tools that facilitate the introduction and presentation of content, communication and the transmission of information. 


\section{CONCLUSIONS}

The evaluation of the experts highlighted the relevance and evaluated as Very adequate the actions of the didactic strategy aimed at guiding the actions for the preparation, execution and evaluation of the training process for scientific research in the student of the career in physical culture, of A way that enables them to use technologies with a meaning and sense of transformation in their research, as well as the acquisition of skills in working with them from home or another space.

Address the research training of students of the career in physical culture, taking into account the diversity of theories and didactic-technological resources, and respond to the need for a new practice for the training process for scientific research with employment in ICT in times of contingency constitutes a challenge at the present time with the accelerated pace of existing technological development.

This research has practical significance, since it favours the development of the training process for scientific research based on ICT in students through accessibility, availability and the collaborative construction of scientific content by them.

\section{REFERENCES}

Acosta Ruiz, L. R. (2019). La formación investigativa de los estudiantes a través de prácticas de laboratorio en el área de ciencia y tecnología. Retrieved from: http://repositorio.unprg.edu.pe/handle/UNPRG/3599

Álvarez, V. M; Orozco, O y Gutiérrez, A. (2011). La Formación De Formación en y para la investigación Profesionales, Una Mirada Desde Las Ciencias Pedagógicas. Cuadernos de Educación y Desarrollo, Grupo Eumed.net (Universidad de Málaga). issue 24. Retrieved from: https://ideas.repec.org/a/erv/cedced/y2011i2412.html

Espinoza, E., Rivera, A. R., y Tinico, N. P. (2016). Formación de competencias investigativas en los estudiantes universitarios. Revista Atenas, 1(33), 18-31.

García M., Linares, A., y Algas L., (2013). La formación investigativa en estudiantes de medicina, desde la enseñanza de pediatría. Revista multimed.sld.c.Vol. 17, No. 1. Retrieved from: http://www.revmultimed.sld.cu/index.php/mtm/article/view/871

Guzmán C. M., (2019). La gestión académica en el nivel superior frente a los desafíos de la formación investigativa de los estudiantes. Revista Multidisciplinaria de Avances de Investigación.Vol. 5 Núm. 1: Retrieved from: http://www.remai.ipn.mx/index.php/REMAl/article/view/52

Jesse, Morris Fernández (2013). La formación de competencias investigativas en los estudiantes de informática mediante el uso de las tecnologías de la información y el conocimiento. Revista Estrategia y Gestión Universitaria Vol. 1, No. 1.

Licona y Veytia (2019). La Formación en y para la investigación y el uso de las Tecnologías de la Información y Comunicación. Revista Atenas Vol.2 Nro. 46.

Morantes, Nava; Arrieta, (2016). Modelo didáctico integrador multimedia para el desarrollo de la formación investigativa, desde un laboratorio de física. Revista Omnia, vol. 22, núm. 3, pp. 11-25. Retrieved from: http://www.redalyc.org/articulo.oa?id=73752819002

Rodríguez (2017). Formación investigativa de los estudiantes desde las prácticas de laboratorio. Revista pedagogía universitaria.

Sánchez (2013).Las TIC en el deporte: Los medios de enseñanza en la Cultura Física y el Deporte. Editorial Académica Española. ISBN-13 : 978-3659062469. 
Sánchez (2009). Las Tecnologías de la Información y las Comunicaciones en la Dinámica del proceso de formación para la investigación científica en la Educación Superior. (Tesis de doctorado inédita). Universidad Oriente. Santiago de Cuba, Santiago de Cuba, Cuba.

Sánchez, Duany y Pozo (2018). Método colaborativo investigativo para la gestión del contenido en diferentes áreas del conocimiento. Revista innova ITFIP, 2 (1), 6-13.

Tourón, Martín, Navarro, Pradas, Íñigo. (2018). Validación de constructo de un instrumento para medir la competencia digital docente de los profesores (CDD). Revista Española de Pedagogía, 25-54.

Cetz, Vásquez, Santiago (2015) Educación con tecnología multimedia: una experiencia en sistemas digitales. Revista Espectros. 